\title{
PROCESI TIJEKOM NALIJEVANJA ZRNA I NJIHOV UTJECAJ NA KAKVOĆU ZRNA PŠENICE NAMIJENJENOG ZA MLINSKO-PEKARSKU INDUSTRIJU
}

\section{THE PROCESSES DURING GRAIN-FILLING AND THEIR IMPACT ON QUALITY OF WHEAT GRAIN INTENDED FOR MILL AND BAKERY INDUSTRY}

\author{
Tamara Brlek, Ž. Jukić, Ana Matković
}

\begin{abstract}
SAŽETAK
Pšenica (Triticum aestivum L.) najvažnija je žitarica za proizvodnju mlinarsko-pekarskih proizvoda. Proces nalijevanja zrna karakterizira nakupljanje organskih i mineralnih tvari u zrnu. Mnogi čimbenici mogu utjecati na proces nalijevanja i kvalitetu zrna pšenice, a neki od njih su: temperatura zraka, oborine, genotip, bolesti i štetnici te primijenjena agrotehnika. Svi ovi čimbenici utječu na kvalitetu zrna pšenice za mlinsko-pekarsku industriju. Temperaturni stres koji se dogodi tijekom ranog perioda nalijevanja zrna, dovodi do najvećeg povećanja sadržaja proteina $u$ pšenici. Promjene $u$ temperaturi mogu utjecati na akumulaciju i sintezu $\alpha$-amilaze u zrnu. Kao i tijekom temperaturnog stresa, u nedostatku vode smanjuje se sadržaj škroba u zrnu. Mnoge bolesti i štetnici pšenice mogu negativno utjecati na usjev, uključujući smanjenje prinosa i hektolitarske mase.
\end{abstract}

Ključne riječi: pšenica, nalijevanje zrna, proteini, škrob

\section{ABSTRACT}

Wheat (Triticum aestivum L.) is the most important cereal for the production of milling and bakery products. Grain filling process is often characterized by accumulation of organic and mineral matter in grain. Grain-filling process and quality of wheat are affected by several factors, including: air temperature, rainfall, genotype, diseases and pests, and applied crop management practices. All, above-mentioned factors influence grain quality for bakery industry and milling business. High temperature stress during the early grain-fill period has been shown to increase wheat grain protein content. Changes in temperature can affect the accumulation and synthesis of $\alpha$-amylase within the grain. Water stress, similar to high temperature, decreases 
Tamara Brlek i sur.: Procesi tijekom nalijevanja zrna i njihov utjecaj na kakvoću zrna pšenice namijenjenog za mlinsko-pekarsku industriju

starch accumulation in the grain. Many diseases and pests can have a negative impact on wheat crop, including decreasing yield and test weight.

Key words: wheat, grain filling, proteins, starch

\section{UVOD}

Pšenica pripada redu Poales, porodici Poaceae (trave), potporodici Pooideae te rodu Triticum (Watson i Dallwitz, 1992. - cit. Živković, 2015.). Pšenica (Triticum aestivum L.) najvažnija je žitarica za proizvodnju mlinarskopekarskih proizvoda te je, uz kukuruz i rižu, najraširenija poljoprivredna kultura na svijetu. Najvažniji je izvor ugljikohidrata, a ukupni udio ugljikohidrata u zrnu pšenice može biti i 80\% (Pospišil, 2010.). Gluten je specifična frakcija proteina pšenice namijenjene za pekarsku industriju, odgovoran je za visokoelastična svojstva pšeničnog tijesta te se koristi kao dodatak hrani za povećanje sadržaja proteina, a kvaliteta glutena utječe na kvalitetu tijesta (Esteller i sur., 2005., Marchetti i sur., 2012. - cit. Ortolan i Steel., 2017.; Perten, 1992. - cit. Ćurić i sur., 2001.; Pospišil, 2010.).

Pšenica, kao i ostale žitarice, tijekom svog životnog ciklusa prolazi kroz 8 faza rasta i razvoja (fenološke faze). Fenološke faze su podijeljene u 2 velika razdoblja, a to su: vegetativno razdoblje (klijanje, nicanje, busanje) i generativno razdoblje (vlatanje, klasanje, cvatnja i oplodnja, formiranje i nalijevanje zrna, zrioba). Početak neke faze računa se kada je $10 \%$ biljaka stupilo u određenu fazu (Pospišil i Pospišil, 2013.). Faza naljevanja zrna definira se kao period između cvatnje i fiziološke zriobe (Przulj i Mladenov, 1999. - cit. Ullah i sur., 2014.). Ako u fazi naljevanja zrna vladaju nepovoljni agroekološki uvjeti poput visokih temperatura, suše, nedostatka hraniva ili pojave bolesti, dolazi do skraćivanja trajanja nalijevanja zrna, što je u negativnoj korelaciji s prinosom i kvalitetom zrna. Takahashi i sur. (1993.) podijelili su period nalijevanja zrna u sljedeće 4 faze: 1. početna faza nalijevanja zrna traje od cvatnje do prestanka izduživanja vlati (asimilati se većinom koriste za izduživanje vlati i za povećanje mase suhe tvari); 2. rana faza nalijevanja zrna traje od prestanka izduživanja vlati do mliječne zriobe (asimilati se koriste za povećanje zrna i pohranjeni su u stabljici); 3. kasna faza nalijevanja zrna traje od mliječne zriobe do prestanka fotosinteze (asimilati se koriste samo za povećanje zrna te se rezervne tvari premještaju u zrno); 4. završna faza nalijevanja zrna traje od prestanka fotosinteze do zrelosti (rast zrna se odvija isključivo translokacijom rezervnih tvari iz stabljike). 
Tamara Brlek i sur.: Procesi tijekom nalijevanja zrna i njihov utjecaj na kakvoću zrna pšenice namijenjenog za mlinsko-pekarsku industriju

Cilj ovog rada bio je, korištenjem dostupne stručne i znanstvene literature, utvrditi koji se procesi odvijaju tijekom nalijevanja zrna te koji čimbenici i na koji način djeluju na kemijski sastav i kakvoću pšenice za mlinsko-pekarsku industriju.

\section{ČIMBENICI KOJI UTJEČU NA PROCES NALIJEVANJA ZRNA PŠENICE}

Čimbenici koji mogu utjecati na proces nalijevanja zrna su: temperatura zraka i svjetlost, oborine, genotip, bolesti i štetnici pšenice te primijenjena agrotehnika. Svi ovi čimbenici utječu na promjene u kakvoći zrna te sastavu i sadržaju proteina i škroba, što posebno utječe na kvalitetu pšenice za mlinskopekarsku industriju.

Utjecaj temperature zraka i oborina tijekom nalijevanja zrna na sadržaj i sastav proteina

Sadržaj proteina jedan je od glavnih parametara koji određuje konačnu kvalitetu pšenice. Promjene u sadržaju i sastavu proteina mogu znatno utjecati na kvalitetu brašna za pekarsku industriju (Weegels i sur., 1996., Lafiandra i sur., 1999., Branlard i sur., 2001. - cit. Triboï i sur., 2003.). Iako sastav proteina u zrnu prvenstveno ovisi o genotipu, na njega značajno utječu okolišni čimbenici i njihova interakcija (Graybosch i sur., 1996.; Triboï i sur., 2000.; Zhu i Khan, 2001., Huebner i sur., 1997. - cit. Martre i sur., 2003.). Proteini pšenice su, s obzirom na njihovu topljivost, podijeljeni u 4 skupine (prema Osbornu): albumini, globulini, glijadini i glutenini (Triboï i sur., 2003.; Wieser i sur. 2014. - cit. Schalk i sur., 2017.), a koristi se i podjela proteina na skladišne, strukturalne i metaboličke, te zaštitne proteine (Shewry i Halford, 2002.).

Dok jedni autori navode kako se tijekom temperaturnog stresa i suše u zrnu stvara više glijadina nego glutenina (Daniel i Triboi, 2000. - cit. Majoul i sur., 2003.; Blumenthal i sur., 1993. - Wrigley i sur., 1994.), drugi autori navode kako visoke temperature uzrokuju akumulaciju glutenina u zrnu (Ciaffi i sur., 1996. - cit. Ferreira i sur., 2012.). Duži period djelovanja visokih temperatura zraka tijekom nalijevanja zrna ili fiziološke zriobe mogu uzrokovati smanjenje čvrstoće tijesta (što je ovisno o koncentraciji proteina u zrnu), imati negativan utjecaj na kvalitetu nekih reoloških svojstava pšenice te masu zrna (Randall i Moss, 1990. - cit. Borghi i sur., 1995.; Graybosch i sur., 1995., Stone i Nicolas 1994. - cit. Stone i Nicholas, 1996.; Blumenthal i sur., 1991., Wardlaw i sur., 2002., Randall i Moss, 1990. - cit. Aguirrezábal i sur., 2015.). 
Tamara Brlek i sur.: Procesi tijekom nalijevanja zrna i njihov utjecaj na kakvoću zrna pšenice namijenjenog za mlinsko-pekarsku industriju

Tijekom visokih temperatura sadržaj proteina u zrnu se povećava (Rao i sur., 1993. - cit. Graybosch, 1995.), iako se masa i veličina zrna smanjuju (McMaster 1997. - Abdrabbo i sur., 2016.; Corbellini i sur., 1997.; Shi i sur., 1994.). Neki autori navode kako je sadržaj proteina u stresnim uvjetima suše i često visoke temperature tijekom nalijevanja zrna obično veći, zato što je period akumulacije škroba kraći nego period akumulacije proteina (Altenbach i sur., 2003. - cit. Konopka i sur., 2007.). Vodni stres u fazi nalijevanja zrna povećava sadržaj proteina pšenice (Zhao i sur. 2005. - cit. Konopka i sur., 2007.). Neki autori navode da je zbog stresa vode, uz povećanje sadržaja proteina i vlažnog glutena, došlo i do smanjenja prinosa i mase 1000 zrna, dok se povećava sadržaj pepela (Nagarajan i sur., 1999., Daniel i Triboï, 2002., Ozturk i Aydin, 2004. cit. Konopka i sur., 2007.) i škroba (Ahmadi i Baker, 2001.; Nagarajan i sur., 1999. - cit. Konopka i sur., 2007.).

Utjecaj temperature zraka i oborina tijekom nalijevanja zrna na sadržaj škroba

Škrob i glukoza mogu formirati linearni polisaharid amilozu $(25 \%)$ i razgranati polisaharid amilopektin (75\%) (BeMiller i Huber, 1996. - cit. Sivam i sur., 2010.). Škroba ima između $60 \%$ i $75 \%$ u masi suhog zrna (Šramková i sur., 2009.), a smanjenje odlaganja škroba je glavni razlog smanjenja mase zrna (Bhullar i Jenner, 1985. - cit. Jenner, 1994.). Škrob se u obliku prozirnih škrobnih granula sintetizira u biljnim organelima koji se zovu amiloplastidi (Naeem i sur., 1997.; Cooper, 2000.; Buléon i sur., 1998., Hancock i Tarbet, 2000. - cit. Matsushima i sur., 2016.). Konačna veličina granule škroba ovisi o kultivaru (Dengate i Meredith, 1984.), temperaturi (Shi i sur., 1994.) i sezoni (Baruch i sur., 1979.).

S obzirom na njihovu veličinu i oblik, granule škroba pšenice mogu biti podijeljene u A i B tip granula (Meredith, 1981., Soulaka i Morrison, 1985. cit. Li i sur., 2016.). Tip granula A (veličina granula: $10-35 \mu \mathrm{m}$ ) sintetizira se u amiloplastu oko 4 do 5 dana nakon cvatnje (Parker, 1985.; Bechtel i sur., 1990. - cit. Shi i sur., 1994.; Gallagher, 2009.), dok se granule tipa B (veličina granula: 1-10 $\mu \mathrm{m}$ ) (Buttrose, 1963., Evers, 1971. - cit. Shi i sur., 1994.) počinju stvarati 10.-14. dana nakon cvatnje i rasta stanica endosperma (Parker, 1985.; Bechtel i sur., 1990. - cit. Shi i sur., 1994.). Postoji i treći C tip granule škroba (veličina granula: $5,3 \mu \mathrm{m}$ ), koji se počinje stvarati 21. dana nakon cvatnje (Bechtel i sur., 1990. - cit. Shi i sur., 1994.). Yan i sur. (2008.) ustanovili su da se volumen granula škroba tipa A značajno povećava, ali da se granule škroba tipa B uvelike smanjuju pod utjecajem visokih temperatura. Ukupni broj 
Tamara Brlek i sur.: Procesi tijekom nalijevanja zrna i njihov utjecaj na kakvoću zrna pšenice namijenjenog za mlinsko-pekarsku industriju

granula škroba sastoji se od $45.7 \%$ granula C-tipa, $49.5 \%$ granula B-tipa, i 4.8\% granula A-tipa. S obzirom na ukupnu masu škrobnih granula u zrelom zrnu, C tip sačinjava 3.4\%, B-tip granula $45.0 \%$, i A-tip granula $51.6 \%$ (Bechtel i sur., 1990. - cit. Wei i sur., 2010.). Pod utjecajem visoke temperature, sadržaj škroba i amilopektina je znatno smanjen, ali koncentracija amiloze može biti povećana ili neznatno smanjena (Zhao i sur., 2006.; Yan i sur., 2008.; Shi i sur., 1994.).

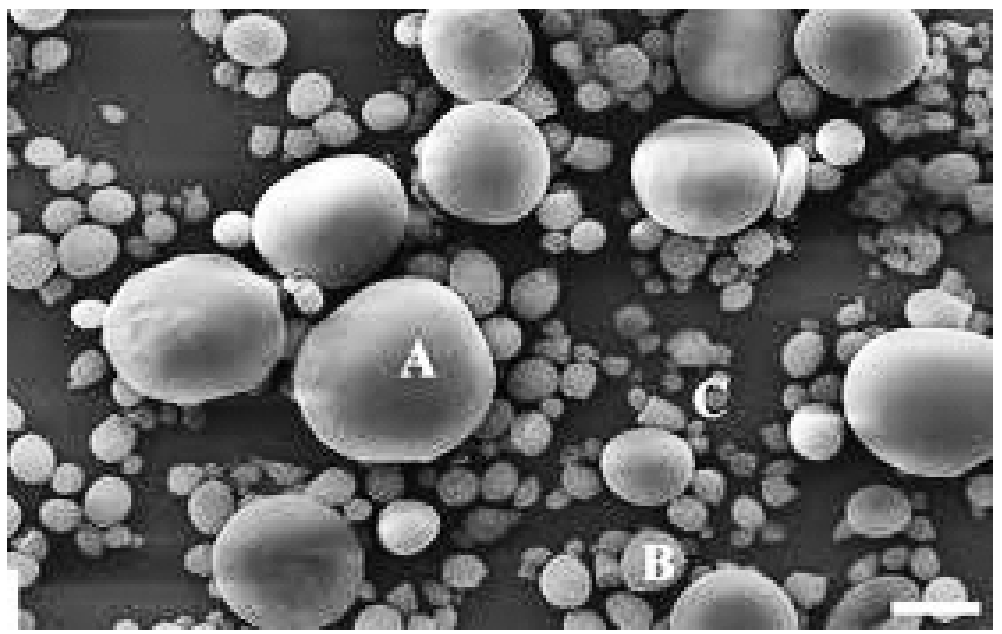

Slika 1: Škrobne granule tipa A, B i C

Figure 1 Starch granules type $A, B$ and $C$

Izvor: Wei i sur., 2010.

Promjena u udjelima granula škroba tipa A, B i C pod utjecajem suše ovisila je o kultivaru te o fazi u kojoj je biljka bila podvrgnuta stresu (8. dana ili 15. dana nakon cvatnje) (Singh i sur., 2008.). U istraživanju Shia i sur. (1994.) utvrđeno je da temperature od 15 do $40^{\circ} \mathrm{C}$ tijekom razdoblja nalijevanja zrna smanjuju masu i veličinu zrna tvrde pšenice (slika 2.). Masa zrna koje je uzgajano pri $40^{\circ} \mathrm{C}$ bila je $38-48 \%$ manja od zrna koje je uzgajano pri $15^{\circ} \mathrm{C}$. Stres visokim temperaturama vidljiv je također i po površini zrna, a takva zrna mogu imati smežuranu površinu. Veličina granula škroba smanjila se pri visokim temperaturama tijekom nalijevanja zrna, te je uočeno nekoliko deformiranih škrobnih granula (Shi i sur. 1994.). 
Tamara Brlek i sur.: Procesi tijekom nalijevanja zrna i njihov utjecaj na kakvoću zrna pšenice namijenjenog za mlinsko-pekarsku industriju
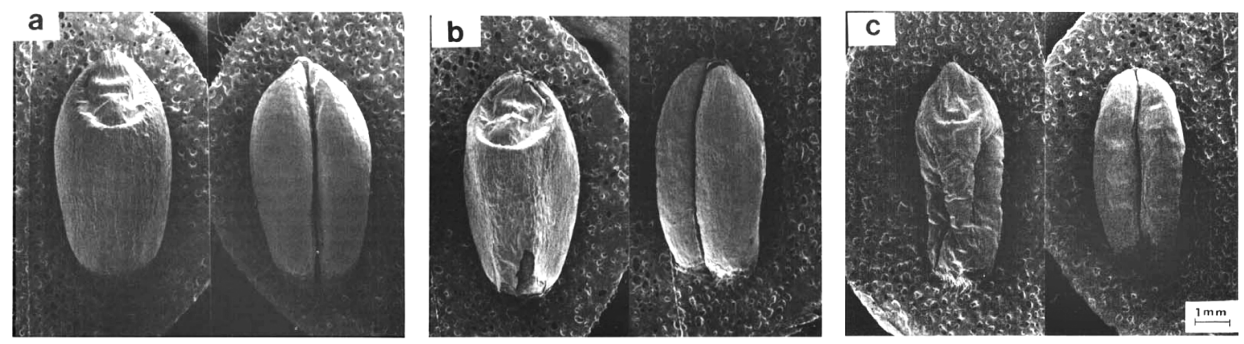

Slika 2. Skenirajuće elektronske mikrografije leđnih i trbušnih strana zrna sorte tvrde pšenice koja je rasla na: a) $18^{\circ} \mathrm{C}$, b) $40^{\circ} \mathrm{C}$, c) tijekom perioda nalijevanja zrna

Figure 2 Scanning electron micrographs of the dorsal and crease sides of kernels grown at: a) $18^{\circ} \mathrm{C}$, b) $40^{\circ} \mathrm{C}$, c) during the grain-filling period Izvor: Shi i sur., 1994. (prilagođeno)

Utjecaj temperature zraka i oborina tijekom nalijevanja zrna na aktivnost $\alpha$ - i $\beta$ - amilaze te na vrijednost broja padanja

Enzimi su proteini čija je komformacija i katalitička aktivnost ovisna o parametrima poput temperature, $\mathrm{pH}$-vrijednosti sredine, koncentracijama supstrata, kemikalijama i dr. (Fagain, 2003.- cit. Vengadaramana i sur., 2014.; Scopes, 2002.). Pri višim temperaturama neki enzimi se denaturiraju i degradiraju (Daniel i sur., 1996.). Aktivnost enzima amilaze tijekom klijanja zrna prije žetve, smatra najvećim uzrokom pada kvalitete škroba u žitaricama te krajnjeg proizvoda zbog degradacije škroba (Ral i sur., 2016.). Enzim se inaktivira pri određenoj temperaturi (Perten, 1964.), te se ne može mjeriti metodom broja padanja po Hagbergu (Hagberg, 1961.) što je standardna metoda određivanja aktivnosti i koncentracije $\alpha$-amilaze (Hagberg, 1960.). Broj padanja po Hagbergu ima obrnuto proporcionalnu vrijednost u odnosu na aktivnost $\alpha$-amilaze, što znači da veća aktivnost enzima daje nižu vrijednost broja padanja i obrnuto. Oborine prije žetve uzrokuju klijanje sjemena na klasu, a klijanje uzrokuje $\alpha$-amilaza ${ }^{1}$.

Utjecaj bolesti i štetnika na kakvoću zrna pšenice

Najčešće bolesti pšenice su: palež klasa (Fusarium spp.), crni bus (Ophiobus graminis), pepelnica (Blumeria graminis f. sp. tritici, syn. Erysiphe graminis f. sp. tritici), hrđe (Puccinia spp.), smeđa pjegavost lišća (Septoria

${ }^{1}$ http://1m5qxn13xidw3q260esedh9c-wpengine.netdna-ssl.com/wp-content/uploads/2016/03/ Falling-Number-Machine-JJLF-Manual.pdf 
Tamara Brlek i sur.: Procesi tijekom nalijevanja zrna i njihov utjecaj na kakvoću zrna pšenice namijenjenog za mlinsko-pekarsku industriju

tritici), smeđa pjegavost pljevica (Septoria nodorum) (Pospišil, 2010.; Conner, 2003. - cit. Zeng, 2014.). Iako smeđa pjegavost lišća može smanjiti sadržaj proteina u brašnu, McKendry i sur. (1995.) pokazali su kako u njihovom istraživanju ta bolest ne uzrokuje smanjenje sadržaja proteina u brašnu. Hrđa pšenice (Puccinia triticina) utječe na smanjenje broja i veličine zrna, smanjuje kvalitetu brašna (Chester, 1946. - cit. Liu i sur., 2014.), te smanjuje konačan prinos zrna (Huerta-Espino i sur., 2011.).

Štetnici koji napadaju zrno pšenice tijekom razvoja uzrokuju značajne ekonomske štete za mlinare i pekare. Hektolitarska masa, masa i veličina zrna, vrijednost Zeleny sedimentacije, kvaliteta proteina brašna te postotak izbrašnjavanja (prinos brašna) smanjuju se s povećanjem stupnja zaraze štetnicima (Karababa i Ozan, 1998.). Stjenice (Aelia spp., Eurygasteri spp.) pri hranjenju u zrna injektiraju proteaze i amilaze koje se nalaze u njihovoj slini (Konarev i sur., 2011. - cit. Salis i sur., 2013.). Proteolitički enzimi, poznati kao peptidaze, proteinaze ili proteaze, su enzimi koji kataboliziraju proteolizu, odnosno razgradnju proteina (The Editors of Encyclopaedia Britannica, 2018.; Varshavsky, 2001.). Zato tijesto dobiveno od zaraženih zrna zbog hidrolize glutena pokazuje manju čvrstoću i veću ljepljivost, dok zrno ima nizak gluten indeks (Kretovich, 1944. - cit. Sivri, 1999.; Cressey i McStay, 1987.; Torbica i sur., 2007.). Posljedica toga je da se smanjuje volumen, tekstura i kvaliteta kruha (Every i sur., 1989.; Kretovich, 1944. - cit. Sivri, 1999.). Eurygaster integriceps ima posebnu gluten hidrolazu koja ima značajnu ulogu u probavi glutena pšenice (Konarev i sur., 2011., Dolgikh i sur., 2014. - cit. Amiri i Bandani, 2016.) te, hranjenjem na listovima, stabljici i zrnju pšenice uzrokuje ozbiljna kvalitativna (uništavanje glutena) i kvantitativna oštećenja (ponekad do 100\%) usjeva (Amiri i Bandani, 2013.; Yandamuri i sur., 2014. - cit. Amiri i Bandani, 2016.). Virus crtičastog mozaika pšenice može smanjiti prinos brašna, no nije utjecao na kvalitetu proteina tvrde pšenice (Finney i Sill, 1963. - cit. McKendry i sur., 1995.).

Brzina i trajanje nalijevanja zrna

Genotip i okolina utječu na brzinu i trajanje nalijevanja zrna (Gallagher i sur., 1974., Bruckner i Frohberg., 1987., Sofield i sur., 1977. - cit. Duguid i Brûlé-Babel, 1994.). Dokazano je kako je brzina i trajanje nalijevanja ovisno i o položaju zrna na klasu (Yang i Zhang, 2006. - cit. Yu i sur., 2014.). Iako je konačna masa suhog zrna pšenice određena brzinom i duljinom trajanja nalijevanja zrna (Motzo i sur., 1996. - cit. Royo i sur., 2006.; Calderini i Reynolds, 2000. - cit. Ullah i sur., 2014.), prinos zrna pšenice po jedinici 
Tamara Brlek i sur.: Procesi tijekom nalijevanja zrna i njihov utjecaj na kakvoću zrna pšenice namijenjenog za mlinsko-pekarsku industriju

površine može biti određen jako ili slabo (Wardlaw i Moncur, 1995., Van Sanford, 1985. - cit. Royo i sur., 2006.; Gebeyehou i sur., 1982. - cit. Ullah i sur., 2014.).

Vodni stres (deficit vode) jedan je od najvažnijih čimbenika koji smanjuje prinos kultiviranih biljaka (Grzesiuk i sur., 1999., Starck i sur., 1995 - cit. Konopka i sur., 2007.). Nedostatak vode u biljci uzrokovan je nedostatkom dostupne vode u tlu, sušom uz koju se često pojavljuju i visoke temperature zraka, te procesom transpiracije (Boczek i Szlendak, 1992., Fordoński i sur., 1994. - cit. Konopka i sur., 2007.).

Tijekom visokih temperatura i suše brzina, odnosno trajanje nalijevanja zrna je skraćeno (Sofield i sur., 1977. - cit. Abdrabbo i sur., 2016.; Nicolas i sur., 1985. - cit. Royo i sur., 2006.). Suša tijekom ranog nalijevanja zrna može uzrokovati smanjenje potencijalnog prinosa i mase zrna (Saini i Westgate, 2000., Dolferus i sur., 2011.- cit. Farooq i sur., 2014.). U istraživanju Wieganda i Cullara (1981.) utvrđeno je da se za svaki porast temperature za $1^{\circ} \mathrm{C}$ skraćuje period nalijevanja zrna do 3,1 dana. U drugim istraživanjima procijenjeno je da se za svaki stupanj iznad optimalne temperature od $15-20^{\circ} \mathrm{C}$, nalijevanje zrna pšenice smanjuje za prosječno 2,8 dana dok se masa zrna smanjuje za $1,5 \mathrm{mg}$ (Marcellos i Single 1972., Bagga i Rawson 1977., Chowdhury i Warlaw 1978. cit. Streck, 2005.). Neki autori navode kako je trajanje nalijevanja zrna kontrolirano sadržajem vode u zrnu, jer se akumulacija suhe tvari zaustavlja pri vlažnosti zrna od 37 - 45 \% (Schnyder i Baum, 1992., Calderini i sur., 2000. cit. Ferreira i sur., 2012.).

\section{ZAKLJUČAK}

Iz istraživane znanstvene i stručne literature vidljivo je da različiti čimbenici djeluju različito na kemijski sastav zrna pšenice tijekom perioda nalijevanja zrna. Period nalijevanja zrna karakterizira nakupljanje organskih i mineralnih tvari u zrnu. Sadržaj proteina u zrnu tijekom djelovanja temperaturnog stresa se povećava, pogotovo tijekom ranog perioda nalijevanja zrna, no funkcionalnost proteina se smanjuje što utječe na konačnu kakvoću. Visoke temperature smanjuju veličinu zrna tako što utječu na odlaganje škroba, tj. sadržaj škroba u zrnu se smanjuje. Sinteza $\alpha$-amilaze je također ovisna o temperaturi. Tijekom suše povećava se sadržaj proteina jer je akumulacija škroba pod većim utjecajem stresa nego što je akumulacija dušika. Međutim, to dovodi i do nekih negativnih promjena poput smanjenja prinosa i mase 1000 zrna. Kao i tijekom temperaturnog stresa, u nedostatku vode smanjuje se sadržaj škroba u zrnu. 
Tamara Brlek i sur.: Procesi tijekom nalijevanja zrna i njihov utjecaj na kakvoću zrna pšenice namijenjenog za mlinsko-pekarsku industriju

Oborine povećavaju količinu $\alpha$-amilaze u zrnu. Genotip i okolina utječu na brzinu i trajanje nalijevanja zrna, dok visoke temperature i suša skraćuju trajanje nalijevanje zrna. Mnoge bolesti i štetnici pšenice utječu na prinos, pojavu smežuranih zrna i smanjenje hektolitarske mase, a u nekim istraživanjima bolesti su smanjile i sadržaj proteina u zrnu.

\section{LITERATURA}

1. Abdrabbo M.A.A., Hashem F.A., Abou-Hadid A.F. (2016.): Irrigation requirements for some bread wheat cultivars in relation to planting dates. Journal of Agricultural Science and Research (JASR). 3(1): 23-40.

2. Aguirrezábal L., Martre P., Pereyra-Irujo G., Echarte M.M., Izquierdo N. (2015.): Improving grain quality: ecophysiological and modeling tools to develop management and breeding strategies. In: Crop Physiology $\left(2^{\text {nd }}\right.$ Edition). Applications for Genetic Improvement and Agronomy, Chapter 17. 423-465.

3. Ahmadi A., Baker D.A. (2001.): The effect of water stress on the activities of key regulatory enzymes of the sucrose to starch pathway in wheat. Plant Growth Regulation. 35(1): 81-91.

4. Amiri A., Bandani A.R. (2013.): Comparison of energy reserves in prediapause and diapausing adult Sunn pest, Eurygaster integriceps Puton (Hemiptera: Scutelleridae). J. Agr. Sci. Tech. 15: 435-444.

5. Amiri A., Bandani A.R., Alizadeh H. (2016.): Molecular identification of cysteine and trypsin protease, effect of different hosts on protease expression, and RNAI mediated silencing of cysteine protease gene in the Sunn Pest. Archives of insect biochemistry and physiology. 91(4): 189-209.

6. Baruch D.W., Meredith P., Jenkins L.D., Simmons L.D. (1979.): Starch granules of developing wheat kernels. Cereal Chem., 56(6): 554-558.

7. Borghi B., Corbellini M., Ciaffi M., Lafiandra D., De Stefanis E., Sgrulletta D., Boggini G., Di Fonzo N. (1995.): Effects of heat shock during grain filling on bread and durum wheats. Aust. J. Agric. Res., 46(7): 1365-1380.

8. Cooper G.M. (2000.): Chloroplasts and Other Plastids. The Cell: A Molecular Approach. $2^{\text {nd }}$ edition. Available at:

https://www.ncbi.nlm.nih.gov/books/NBK9905/

9. Corbellini M., Canevar M.G., Mazza L., Ciaffi M., Lafiandra D., Borghi B. (1997.): Effect of the duration and intensity of heat shock during grain filling on dry matter and protein accumulation, technological quality and protein composition in bread and durum wheat. Australian Journal of Plant Physiology. 24(2): $245-260$. 
Tamara Brlek i sur.: Procesi tijekom nalijevanja zrna i njihov utjecaj na kakvoću zrna pšenice namijenjenog za mlinsko-pekarsku industriju

10. Cressey P.J., McStay C.L. (1987.): Wheat-bug damage in New Zealand wheats. Development of a simple SDS-sedimentation test for bug damage. J. Sci. Food. Agric., 38(4): 357-366.

11. Curić, D., Karlović, D., Tušak, D., Petrović, B., Đugum J. (2001.): Gluten as a standard of wheat flour quality. Food Technol. Biotechnol. 39(4): 353-361.

12. Daniel R.M., Dines M., Petach H.H. (1996.): The denaturation and degradation of stable enzymes at high temperatures. Biochemical Journal, 317: 1-11.

13. Dengate H., Meredith P. (1984.): Variation in size distribution of starch granules from wheat grain. J. Cereal Sci., 2(2):83-90.

14. Duguid S.D., Brûlé-Babel A.L. (1994.): Rate and duration of grain filling in five spring wheat (Triticum aestivum L.) genotypes. Canadian Journal of Plant Science. 74(4): 681-686.

15. Every D., Farrell J.A.K., Stufkens M.W. (1989.): Effect of Nysius huttoni on the protein and baking properties of two New Zealand wheat cultivars. J. Crop Hortic. Sci. 17(1): 55-60.

16. Farooq M., Hussain M., Siddique K.H.M. (2014.): Drought Stress in Wheat during Flowering and Grain-filling Periods. Critical Reviews in Plant Sciences, 33(4): 331-349.

17. Ferreira M.S.L., Martre P., Mangavel C., Girousse C., Rosa N.N., Samson M.F., Morel M.H. (2012.): Physicochemical control of durum wheat grain filling and glutenin polymer assembly under different temperature regimes. Journal of Cereal Science. 56(1): 58-66.

18. Gallagher E. (2009.): Gluten-Free Food Science and Technology. WileyBlackwell, 206.

19. Graybosch R.A., Peterson C.J., Baenziger P.S., Shelton D.R. (1995.): Environmental modification of hard red winter wheat flour protein composition. Journal of Cereal Science, 22:45-51.

20. Graybosch, R.A., Peterson, C.J., Shelton, D.R., Baenziger, P.S. (1996.): Genotypic and environmental modification of wheat flour protein composition in relation to end-use quality. Crop Sci., 36:296-300.

21. Hagberg S. (1960.): A rapid method for determining alpha-amylase activity. Cereal Chem 37:218 - 222.

22. Hagberg S. (1961.): Note on a simplified rapid method for determining alphaamylase activity. Cereal Chem. 38: 202-203.

23. Huerta-Espino J., Singh R.P., Germán S., McCallum B.D., Park R.F., Chen W.Q., Bhardwaj S.C., Goyeau, H. (2011.). Global status of wheat leaf rust caused by Puccinia triticina. Euphytica, 179(1): 143-160. 
Tamara Brlek i sur.: Procesi tijekom nalijevanja zrna i njihov utjecaj na kakvoću zrna pšenice namijenjenog za mlinsko-pekarsku industriju

24. Jenner C.F. (1994.): Starch synthesis in the kernel of wheat under high temperature conditions. Aust. J. Plant Physiol., 21: 791-806.

25. Karababa E., Ozan A.N. (1998.): Effect of wheat bug (Eurygaster integriceps) damage on quality of a wheat variety grown in Turkey. J Sci Food Agric., 77(3): 399-403.

26. Konopka I., Tańska M., Pszczółkowska A., Frodoński G., Kozirok W., Oszewaki J. (2007.): The effect of water stress on wheat kernel size, color and protein composition. Pol. J. Natur. Sci., 22(2): 157-171. Available at: http://www.uwm.edu.pl/stas/wydawnictwo/04.02/polish22_2-2007.pdf

27. Li W., Yan S., Shi X., Zhang C., Shao Q., Xu F., Wang J. (2016.): Starch granule size distribution from twelve wheat cultivars in east China's Huaibei region. Canadian Journal of Plant Science, 96(2): 176-182.

28. Liu M., Rodrigue N., Kolmer J. (2014.): Population divergence in the wheat leaf rust fungus Puccinia triticina is correlated with wheat evolution. Heredity (Edinb)., 112(4): 443-453.

29. Majoul T, Bancel E., Triboï E., Ben Hamida J., Branlard G. (2003.): Proteomic analysis of the effect of heat stress on hexaploid wheat grain: Characterization of heat-responsive proteins from total endosperm. Proteomics., 3(2):175-183.

30. Martre P., Porter J.R., Jamieson P.D., Triboï E. (2003.): Modeling grain nitrogen accumulation and protein composition to understand the sink/source regulations of nitrogen remobilization for wheat. Plant Physiol., 133(4): 19591967.

31. Matsushima R., Maekawa M., Kusano M., Tomita K., Kondo H., Nishimura H., Crofts N., Fujita N., Sakamoto W. (2016.): Amyloplast membrane protein SUBSTANDARD STARCH GRAIN6 controls starch grain size in rice endosperm. Plant Physiol. 170(3): 1445-59.

32. McKendry A.L., Henke G.E., Finney P.L. (1995.): Effects of Septoria leaf blotch on soft red winter wheat milling and baking quality. Cereal Chem., 72(2):142-146

33. Naeem M., Tetlow I.J., Emes M.J. (1997.): Starch synthesis in amyloplasts purified from developing potato tubers. The Plant Journal, 11(5):1095-1103.

34. Ortolan F., Stell C.J. (2017.): Protein characteristics that affect the quality of vital wheat gluten to be used in baking: A review. Comprehensive Reviews in Food Science and Food Safety. 16(3): 369-381.

35. Parker M.L. (1985.): The relationship between A-type and B-type starch granule in the developing endosperm of wheat. J. Cereal Sci. 3:271-278.

36. Perten H. (1964.): Application of the falling number method for the evaluating alpha-amylase activity. Cereal Chem., 41(3): 127-140. 
Tamara Brlek i sur.: Procesi tijekom nalijevanja zrna i njihov utjecaj na kakvoću zrna pšenice namijenjenog za mlinsko-pekarsku industriju

37. Pospišil A. (2010.): Ratarstvo I. dio. Zrinski d.d., Čakovec, str. 7, 33.

38. Pospišil A., Pospišil M. (2013.): Ratarstvo - praktikum. Sveučilište u Zagrebu, Agronomski fakultet, Zagreb (priručnik).

39. Ral J.P., Whan A., Larroque O., Leyne E., Pritchard J., Dielen AS., Howitt C., Morell M., Newberry M. (2016.): Engineering high $\alpha$-amylase levels in wheat grain lowers Falling Number but improves baking properties. Plant Biotechnol J. 14(1): 364-376.

40. Royo C., Villegas D., Rharrabti Y., Blanco R., Martos V., García del Moral L.F. (2006.): Grain growth and yield formation of durum wheat grown at contrasting latitudes and water regimes in a Mediterranean environment. Cereal Research Communications, 34(2/3): 1021-1028.

41. Salis L., Goula M., Izquierdo J., Gordún E. (2013.): Population density and distribution of wheat bugs infesting durum wheat in Sardinia, Italy. J Insect Sci., 13: 50.

42. Schalk K., Lexhaller B., Koehler P., Scherf K.A. (2017.): Isolation and characterization of gluten protein types from wheat, rye, barley and oats for use as reference materials. PLoS ONE, 12(2): e0172819.

43. Scopes R.K. (2002.): Enzyme Activity and Assays. In: ENCYCLOPEDIA OF LIFE SCIENCES, Macmillan Publishers Ltd, Nature Publishing Group, 1-6.

44. Shewry P.R., Halford N.G. (2002.): Cereal seed storage proteins: structures, properties and role in grain utilization. J. Exp. Bot., 53(370): 947-958.

45. Shi Y.C., Seib P.A., Bernardin J.E. (1994.): Effects of temperature during grain-filling on starches from six wheat cultivars. Cereal Chem., 71(4): 369-383.

46. Singh S., Singh G., Singh P., Singh N. (2008.): Effect of water stress at different stages of grain development on the characteristics of starch and protein of different wheat varieties. Food Chem., 108(1): 130-139.

47. Sivam A.S., Sun-Waterhouse D., Quek S., Perera C.O. (2010.): Properties of bread dough with added fiber polysaccharides and phenolic antioxidants: A review. J Food Sci., 75(8): R163-R174.

48. Sivri D., Sapirstein H.D., Köksel H., Bushuk W. (1999.): Effects of wheat bug (Eurygaster maura) protease on glutenin proteins. Cereal Chem., 76(5): 816-820.

49. Stone P., Nicolas M. (1996.): Varietal differences in mature protein composition of wheat resulted from different rates of polymer accumulation during grain filling. Func. Plant Biol. 23(6): 727-737. 
Tamara Brlek i sur.: Procesi tijekom nalijevanja zrna i njihov utjecaj na kakvoću zrna pšenice namijenjenog za mlinsko-pekarsku industriju

50. Streck N.A. (2005.): Climate change and agroecosystems: the effect of elevated atmospheric $\mathrm{CO} 2$ and temperature on crop growth, development, and yield. Cienc. Rural., 35(3): 730-740.

51. Šramková Z., Gregová E., Šturdík E. (2009.): Chemical composition and nutritional quality of wheat grain. Acta Chimica Slovaca, 2(1):115 - 138.

52. Takahashi T., Tsuchihashi N., Nakaseko K. (1993.): Grain filling mechanisms in spring wheat: I. Grain filling phases according to the development of plant organs. Japanese journal of crop science. 62(4):560-564.

53. The Editors of Encyclopaedia Britannica (2018.): Proteolytic enzyme. Available at: https://www.britannica.com/science/proteolytic-enzyme Pristupljeno: 16.06.2018.

54. Torbica A., Antov M., Malistović J., Knežević D. (2007.): The influence of changes in gluten complex structure on technological quality of wheat (Triticum aestivum L.). Food research international, 40(8): 1038-1045.

55. Triboï E., Martre P., Triboï-Blondel A.M. (2003.): Environmentally-induced changes in protein composition in developing grains of wheat are related to changes in total protein content. J. Exp. Bot., 54(388): 1731-1742.

56. Triboï E., Abad A., Michelena A., Lloveras J., Ollier J.L., Daniel C. (2000.): Environmental effects on the quality of two wheat genotypes: 1 . quantitative and qualitative variation of storage proteins. European Journal of Agronomy, 13: 47-64.

57. Ullah K., Khan N.U., Khan S.J., Khan I.U., Khan M.I., Khan R.U., Gul S. (2014.): Genetic analysis for grain filling duration in wheat using joint segregation analysis. Turkish Journal of Agriculture and Forestry, 38: 807-819.

58. Varshavsky A. (2001.): Proteolysis. In: Brenner S., Miller J.H.: Encyclopedia of Genetics. Academic Press. $1^{\text {st }}$ Ed. 1573-1575.

59. Vengadaramana A., Balakumar S., Arasaratnam V. (2014.): Effect of temperature, $\mathrm{pH}$, substrate (Starch) and glucose on stability of $\alpha$ - amylase from Bacillus licheniformis ATCC 6346. Sch. Acad. J. Pharm., 3(6): 492-495.

60. Wei C., Yifang Z., Chen Y, Zhou W., Xu B., Wang Y., Chen J. (2010.): Physicochemical properties and development of wheat large and small starch granules during endosperm development. Acta Physiologiae Plantarum, 32(5): 905-916.

61. Wiegand C. L., Cullar J. A. (1981.): Duration of grain filling and kernel weight of wheat as affected by temperature. Crop Sci., 21(1): 95-101.

62. Wrigley C.W., Blumenthal C., Gras P.W., Barlow E.W.R. (1994.): Temperature variation during grain-filling and changes in wheat grain quality. Australian Journal of Plant Physology, 21(6) : 875 - 885. 
Tamara Brlek i sur.: Procesi tijekom nalijevanja zrna i njihov utjecaj na kakvoću zrna pšenice namijenjenog za mlinsko-pekarsku industriju

63. Yan S.H., Yin Y.P., Li W.Y., Li Y., Liang T.B., Wu Y.H., Geng Q.H., Wang Z.L. (2008.): Effect of high temperature after anthesis on starch formation of two wheat cultivars differing in heat tolerance. Acta Ecol. Sin., 28: 6138-6147.

64. Yu A., Li Y., Ni Y., Yang W., Yang D., Cui Z., Wang Z., Yin Y. (2014.): Differences of Starch Granule Distribution in Grains from Different Spikelet Positions in Winter Wheat. PLoS ONE, 9(12): e114342.

65. Zeng F., Yang L., Gong S., Shi W., Zhang X., Wang H., Xiang L., Xue M., $\mathrm{Yu}$ D. (2014.). Virulence and diversity of Blumeria graminis $\mathrm{f}$. sp. tritici populations in China. J. Integr. Agric., 13(11), 2424-2437.

66. Zhao H., Dai T.B., Jing Q., Jiang D., Cao W.X., Lu W., Tian X.W. (2006.): Effects of high temperature during grain filling on key enzymes involved in starch synthesis in two wheat cultivars with different quality types. Acta Agronomica Sinica, 32:423-429.

67. Živković M. (2015): Utjecaj gnojidbe i obrade tla na zarazu zrna pšenice Fusarium vrstama. Diplomski rad, Sveučilište Josipa Jurja Strossmayera, Poljoprivredni fakultet u Osijeku. Available at:

https://repozitorij.pfos.hr/islandora/object/pfos:93/preview

68. http://1m5qxn13xidw3q260esedh9c-wpengine.netdna-ssl.com/wpcontent/uploads/2016/03/Falling-Number-Machine-JJLF-Manual.pdf (Pristupljeno: 17.09.2018.)

Adrese autora - Author's addresses:

Tamara Brlek, univ.bacc.ing.agr, student Izv. prof. dr. sc. Željko Jukić, e-mail: zjukic@agr.hr Ana Matković, mag.ing.agr.

Agronomski fakultet, Zavod za specijalnu proizvodnju bilja, Svetošimunska cesta 25, 10000 Zagreb
Primljeno-received:

20.09.2018. 